\title{
The role of personality and intercultural effectiveness towards study abroad academic and social activities
}

\author{
Wang, Wen-Lin \\ Graduate Institute of Educational Leadership and Development, Fu Jen Catholic University, Taiwan \\ (050878@mail.fju.edu.tw) \\ Ching, Gregory S. \\ Graduate Institute of Educational Leadership and Development, Fu Jen Catholic University, Taiwan \\ (gregory_ching@yahoo.com)
}

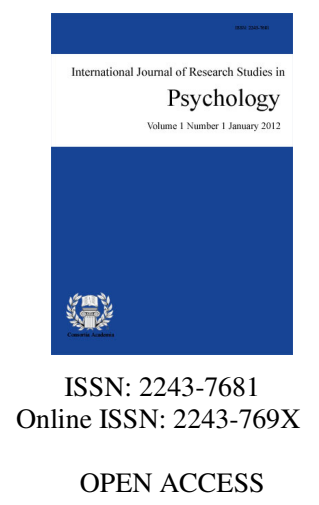

Received: 24 March 2015

Revised: 20 September 2015

Available Online: 5 October 2015

DOI: $10.5861 /$ ijrsp.2015.774

Accepted: 1 October 2015

\begin{abstract}
With the current trend of higher education study abroad exchanges, opportunities for travelling and studying in another country are at an all-time high. These exchanges are noted for providing both academic and sociocultural benefits. However, these heightened opportunities have also started to cause parents and academics to wonder about the quality of such experiences. Literature suggests that the students' personality and their intercultural competencies play an important role in the success of their study abroad experience. In Taiwan, due to the decreasing number of local incoming students, higher education institutions are gearing up in becoming quality venues of study abroad programs. Hence, understanding how study abroad students are doing in Taiwan is quite crucial in attracting future enrollees. In light of these issues, the current paper presents the findings of a quantitative study accomplished during the fall semester of 2014 in Taiwan. A total of 888 volunteer foreign students participated in a survey which includes the 44 items Big-Five Personality Inventory (BFI) and the 20 item Intercultural Effectiveness Scale (IES). In addition, the frequency and satisfaction of both academic and social activities are also asked. Results were then tabulated and computed using the software SPSS. Findings show that the various IES factors are positively correlated with BFI factors with the exception of neuroticism, which is negatively correlated. In addition, results also show that there exists a significant gender difference among the students' interaction relax and interaction management factors, and also with the personalities of conscientiousness, openness, and neuroticism. Lastly, results show that there are significant differences in all the IES and BFI factors with regards to the different students' enrolment ethnic categories and academic and social activities. Such results indicate that both academic and social activities during study abroad are much dependent on the students' personality and their intercultural competencies. Hence, it is suggested that prior/arrival intercultural workshops be accomplished in order to ease the adjustment process.
\end{abstract}

Keywords: study abroad; interaction-relax; interaction-management; gender differences; personality 


\section{The role of personality and intercultural effectiveness towards study abroad academic and social activities}

\section{Introduction}

The global emphasis on higher education internalization has led to the proliferation of study abroad opportunities for students. In Taiwan, facing the challenges of having one of the lowest birth-rate in the world; the decreasing number of incoming local students is seen as an opportunity to open-up the campus for additional international enrolment. Hence, Taiwan's higher education institutions are gearing up in becoming quality venues of study abroad programs. However, with the various available study abroad programs, doubts regarding the perceived quality of such experiences are started to increased. Parents need to be assured that the cost of study abroad will in turn make their children more mature and return home ready to face future challenges. In addition, not all school administrators and faculty are convinced that studying abroad would automatically enhances their students' knowledge, perspective, and skills fit for living and working in a globalized society (Vande Berg, Paige, \& Lou, 2012a, p. 5).

In a more traditional and practical way of thinking, study abroad experience should be described in terms of meaningful learning outcomes (Orahood, Kruze, \& Pearson, 2004, p. 128). On the contrary, recent studies have shown that some students are not even serious during their study abroad duration, they prefer a surface approach to learning instead of being able to participate and think critically (Sakurai, Pyhältö, \& Lindblom-Ylänne, 2014); the surface approach to learning is characterized by students' attempts to memorize and reproduce factual content without a strong underlying understanding (p. 136). Nonetheless, relying on study abroad students themselves to become an active learner seems not to be the case, but it should be the shared responsibility of both the institution and the student themselves to instill a sense of deep learning and academic engagement (Lillyman \& Bennett, 2014); deep learning is based more on the understanding, and constructing an understanding of the learned contents (Biggs \& Tang, 2007), a process that promote higher order thinking skills (such as critical thinking). To better understand how institutions are able to help study abroad students, first and foremost, analysis should be done on the various factors that would affect these students, for instance the students' intercultural competencies, so as to provide interventions in promoting (or to develop) such competencies.

In another spectrum, evidence does show the success of global study abroad programs. The recent increased in numbers of study abroad students to an almost 5 million for 2014 have proven to be a huge increase of $40 \%$ since 2000 (Maslen, 2014). These increased in numbers would signify that students must be learning something (Vande Berg, Paige, \& Lou, 2012b). For the past decade, many scholars have tried to determine the effects brought about by participating in study abroad programs (Roy, Wandschneider, \& Steglitz, 2014). In a report on study abroad students from the United States, Norris and Gillespie (2009) noted that significant improvement on students' future career are seen in terms of foreign language use and up keeping of international contacts. Similar findings were also noted in an earlier study by Dwyer (2004) wherein implications for career improvements and intercultural skills development are seen in employees who have previous study abroad experiences during college. One study even pointed out that even the short-term exchanges are able to provide significant improvement on students' intercultural awareness (Chieffo \& Griffiths, 2004). Such evidences seem to suggest that intercultural learning and development as the key benefit brought about by study abroad experiences.

Recent research trends are also quite focus on the psychosocial adjustment of students (Wang \& Hannes, 2014; Zhang \& Goodson, 2011a, 2011b). Some have implied the need for improving the students' social connectedness (Hendrickson, Rosen, \& Aune, 2011); which is define by the perceived emotional distance or connectedness between the individual and other people (p. 286). These are in turn manifested through the quality 
The role of personality and intercultural effectiveness towards study abroad academic and social activities

and frequency of the study abroad students' interactions with their three groups of friends (host national, co-national, and multi-national). Actually, an early study by Bochner, McLeod, and Lin (1977) noted that there exists a sort of subjective hierarchy among the three groups, which is quite dependent on the type of activities being accomplished. Such notion opens up the discussions regarding the definition, concepts, and including the role friendship among the study abroad students (and the three groups; including the notion of in-groups and out-groups), which in fact have already become an inseparable part of the study abroad students' psychosocial adjustment (Glass, Gomez, \& Urzua, 2014; Huang, Chen, \& Ching, 2014; C. T. Williams \& Johnson, 2011).

Some recent reports have even mentioned that study abroad experiences are able to positively benefit students' personality development (Inside Higher Ed, 2013; Wood, 2013; Zimmermann \& Neyer, 2013). In a study by Bakalis and Joiner (2004), they mentioned that the personality trait of openness is key to having a successful study abroad experience. They further added that the students' level of openness is quite associated with their willingness to join these educational and cultural exchanges. In addition, Leong (2007) study of Singaporean undergraduate students who undertaken an exchange have shown to have also noted higher levels of intercultural competencies. In light of their findings, it is can be noted that both students' personality and their intercultural competencies are inter-related in the overall quality of their study abroad experiences. Hence, understanding the students' personality, intercultural competencies, and together with their academic and social activities shall shed light to how these factors are inter-related with each other.

\section{Methodology}

\subsection{Research setting and objective}

Recently, in Taiwan, a serious predicament within higher education institutions is the decreasing number of local incoming (freshmen) students. This issue have inevitably cost a lot of financial difficulties for Taiwan academic institutions (D.-S. Chen \& Chang, 2010). To solve this problem, Taiwan higher education institutions have started to recruit various types of foreign students. Within the Taiwan Ministry of Education, there are four distinct category foreign student groups, namely: International students (IS), mainland Chinese students (MCS), Hong Kong and Macau students (HKM), and overseas Chinese students (OCS) (Ministry of Education, 2014). For clarity, OCS are those students who are of Chinese ethnicity and are born overseas and still living, or have lived abroad for more than six years and have a permanent residence or have obtained long-term residency in a foreign country (excluding those coming from Hong Kong and Macau; they are considered HKM students).

In light of the previous mentioned issues, the current study is anchored in the following research objectives:

$>\quad$ To determine the personality differences among the various foreign student groups in Taiwan;

$>\quad$ To determine the intercultural competency differences among the various foreign student groups in Taiwan;

$>$ To determine if there are any gender differences among the personalities and intercultural competencies;

$>\quad$ To determine the study abroad academic and social activity differences among the various foreign student groups in Taiwan; and

$>\quad$ To determine the role of personality and intercultural effectiveness towards study abroad academic and social activities.

\subsection{Research design}

The current study employed the descriptive research paradigm; a research that is typically concerned with 
how something that exists is related to some preceding event, which has influenced or affected a present condition or event. Descriptive research, according to Best (1970) is concerned with conditions or relationships that exist, practices that prevail, beliefs, points of views, or attributes that are held, processes that are ongoing, effects that are being felt; or developing trends. Furthermore, this study is also cross-sectional in design. Cross-sectional meaning that the research is accomplished within a certain point in time without any manipulation of the study environment (Atwork, 2009). Hence, collected data should be able to provide insights on the better understanding on how study abroad students are currently doing. In effect, should be able to help Taiwan host institutions in better handling the difficulties study abroad students are encountering and thus provide a better venue for future school choice.

\subsection{Big Five Personality Inventory (BFI)}

The Big Five personality trait have been derived from various research and seminal works of Allport and Odbert (1936), Fiske (1949), Tupes and Christal (1961), and Norman (1963), and the more recent studies by Goldberg (1993) and McCrae and Costa (1996, 2003). The Big Five personality traits are composed of the following (with their corresponding opposing traits) (Hogan \& Hogan, 1992; Hogan, Johnson, \& Briggs, 1997; Pervin \& John, 1999; Potkay \& Allen, 1986), such as: Extraversion (introversion): denotes a person who is talkative, social, and assertive; Agreeableness (antagonism): denotes a person who is of good natured, co-operative, and trusting; Conscientiousness (un-directedness): denotes a person who is responsible, orderly, and dependable; Neuroticism (emotional stability): denotes a person who is anxious, prone to depression, and worries a lot; and Openness to experience (not open to experience): denotes a person who is imaginative, independent minded, and has divergent thinking. In essence, the Big Five personality structure is said to be able to described at a broad level of abstraction, the commonalities among most of the existing systems of personality description, and provides an integrative descriptive model for personality research (John \& Srivastava, 1999, p. 131).

For the current study, the researcher make use of the tool developed by John, Donahue, and Kentle (1991); the 44 items Big Five Inventory (BFI). The main features of the BFI are its short phrased items. The BFI does not use single adjectives as items, because such items are answered less consistently than when they are accompanied by definitions or elaborations; instead the BFI uses short phrases (Goldberg \& Kilkowski, 1985). The goal of BFI is to create a brief inventory that would allow efficient and flexible assessment of the five personality traits (John \& Srivastava, 1999; Rammstedt \& John, 2007). More importantly, Cronbach Alpha reliabilities of the BFI in general (except in situations wherein the population samples are considered indigenous) are considered to be moderate high (Gurven, von Rueden, Massenkoff, Kaplan, \& Lero Vie, 2013; Gurven, von Rueden, Stieglitz, Kaplan, \& Rodriguez, 2014). Hence, the BFI items retain the advantages of adjectival items (brevity and simplicity) while avoiding some of their pitfalls (ambiguous or multiple meanings and salient desirability) (John \& Srivastava, 1999, p. 115).

\subsection{Intercultural effectiveness}

Within a seminal literature, Byram (1997) proposed to define intercultural competence as the ability to see relationships between different cultures - both internal and external to a society and to mediate, which is to interpret in each other terms, either for themselves or for other people (p. 12). This actually includes the ability to critically understand one's own and other cultures (G. M. Chen \& Starosta, 2000). Studies have shown that students who participates in study abroad are able to develop and enhance their intercultural competence (Sinicrope, Norris, \& Watanabe, 2007). Intercultural competence in itself shows the ability to recognize, respect, value and use productively cultural conditions and orientation patterns with respect to interpreting and shaping the world. Intercultural competence of an individual can actually be used to measure or evaluate the outcomes of study abroad programs (Marx \& Moss, 2011; Parsons, 2010). More importantly, these competences seem to lead to the ability of being able to become sensitive to various intercultural situations (Anderson, Lawton, Rexeisen, \& Hubbard, 2006), adapt and communicate effectively (T. R. Williams, 2005), and their overall attitudes towards 
The role of personality and intercultural effectiveness towards study abroad academic and social activities

foreign cultures (Carlson \& Widaman, 1988).

For the current study, in order to understand the study abroad students' intercultural competence, the 20 item Intercultural Effectiveness Scale (IES) by Portalla and Chen (2010) was used. Factors within the IES includes: Behavioral flexibility - these refers to the ability to observe, distinguish, and adapt to an interaction within a specific situational context; Interaction relaxation - these refers to the approachability, openness, and overall comfort level during interactions; Interactant respect - these refers to the level of value placed upon the culturally different counterpart; Message skills - these refers to the ability to use and understand verbal and nonverbal cues; Identity maintenance - these refers to the ability to maintain the unique identity of the culturally different counterpart while also maintaining one's own separate identity; and Interaction management - these refers to the ability to express ideas and answer questions (Portalla \& Chen, 2010, pp. 25-26). Cronbach Alpha reliability of the IES was computed to be at .85 , which is considered to be highly reliable (L. Cohen, Manion, \& Morrison, 2007).

\subsection{Procedure and study participants}

To collect the study abroad students' feedback, an online survey was administered during the middle of the fall semester of 2014. A call for participation was made in the international office of a private university in Northern Taiwan. At the end of the survey, a total of 888 volunteer students participated in a survey which includes the 44 items BFI personality scale by John and Srivastava (1999), the 20 item IES by Portalla and Chen (2010), academic and social interaction frequencies, and other demographical backgrounds. Results were tabulated and computed using the software Social Package for Social Scientists (SPSS). Overall Cronbach's alpha reliability of the survey is computed at .72, considered to be reliable results (L. Cohen et al., 2007). Table 1 shows that almost half of the participants are IS with 433 or $48.8 \%$, followed by MCS with 270 or $30.4 \%$, OCS with 99 or $11.1 \%$, and lastly HKM with 86 or $9.7 \%$. Table 2 shows a more detailed by country participants separated by gender denoting an almost equal number of male and female respondents. Mean age of participants is 21 years old, while the average stay in Taiwan is around 18 mounts.

Table 1

Student participants categorized by student groups $(N=888)$

\begin{tabular}{|c|c|c|}
\hline Student groups & Frequency & Percent \\
\hline International students (IS) & 433 & 49 \\
\hline Mainland Chinese students (MCS) & 270 & 30 \\
\hline Oversea Chinese students (OCS) & 99 & 11 \\
\hline Hong Kong / Macau students (HKM) & 86 & 10 \\
\hline & 888 & 100 \\
\hline
\end{tabular}

\section{Results and discussions}

\subsection{Personality}

To collect the students' personality traits, the 44 items BFI was used. Students are ask to rate their perceived levels of agreement with the various statements. A five point Likert-type scale was used. Ratings were 1 as disagree strongly, 2 as disagree a little, 3 as neither agree nor disagree, 4 as agree a little, and 5 as agree strongly. Scoring for the BFI is as follows ( $\mathrm{R}$ denoting reverse-scored items) (John \& Srivastava, 1999): extraversion $=1$, $6 \mathrm{R}, 11,16,21 \mathrm{R}, 26,31 \mathrm{R}, 36$; agreeableness $=2 \mathrm{R}, 7,12 \mathrm{R}, 17,22,27 \mathrm{R}, 32,37 \mathrm{R}, 42$; conscientiousness $=3$, 8R, 13,18R, 23R, 28, 33, 38, 43R; neuroticism = 4, 9R, 14, 19, 24R, 29, 34R, 39; and openness = 5, 10, 15, 20, 25, 30, 35R, 40, 41R, 44. Cronbach Alpha reliability of the BFI is computed at .74, which can be considered to be reliable results (L. Cohen et al., 2007). Responses from the corresponding items are then added together to form the various scores of the personality traits. Table 3 shows the result for the personality of the overall participants and together with the different student groups. Looking at the results, it would seem that MCS scored highest on 
Wang, W.-L., \& Ching, G. S.

the personality traits extraversion, agreeableness, and openness, while IS scored highest on personality trait conscientiousness, and lastly HKM scored highest on the personality trait neuroticism.

Table 2

Study participants' country of origin $(N=888)$

\begin{tabular}{lrrrr}
\hline & \multirow{2}{*}{ Country } & \multicolumn{2}{c}{ Gender } & \multicolumn{2}{c}{$n$} \\
\cline { 2 - 3 } & Female & \multicolumn{1}{c}{ Male } & & \multicolumn{2}{c}{$\%$} \\
\hline China & 167 & 103 & 270 & 30 \\
Hong Kong & 28 & 26 & 54 & 6 \\
Macau & 15 & 17 & 32 & 4 \\
Indonesia & 52 & 52 & 104 & 12 \\
Malaysia & 47 & 59 & 106 & 12 \\
Vietnam & 26 & 34 & 60 & 7 \\
Singapore & 17 & 9 & 26 & 3 \\
India & 4 & 17 & 21 & 2 \\
US & 7 & 13 & 20 & 2 \\
Philippines & 9 & 8 & 17 & 2 \\
Thailand & 9 & 4 & 13 & 2 \\
Germany & 7 & 5 & 12 & 1 \\
South Korea & 5 & 7 & 12 & 1 \\
France & 7 & 4 & 11 & 1 \\
Japan & 1 & 6 & 7 & 1 \\
Mongolia & 6 & 1 & 7 & 1 \\
Honduras & 2 & 5 & 7 & 1 \\
Gambia & 0 & 6 & 6 & 1 \\
Belize & 2 & 3 & 5 & 1 \\
Nicaragua & 1 & 4 & 5 & 1 \\
Russia & 4 & 1 & 5 & 1 \\
others & 45 & 43 & 88 & 9 \\
\hline
\end{tabular}

Note. Average age is 21 years old. Average months of stay $=18$ months.

To better understand whether these differences in mean scores are statistically significant, an Analysis of Variance (ANOVA) was accomplished. Table 4 shows the ANOVA results with all of the five personality having significant differences among the different student groups. In addition, the effect sizes are also provided in terms of Eta squared values. Eta squared values are from .020 to .068 suggesting small (.01 to .05$)$ to moderate (.06 to .13) effect sizes (J. Cohen, 1988). Lastly, post-hoc analyses are also provided in Table 4, noting the significant differences between group comparisons. ANOVA results do suggest that the personality differences among the student groups are meaningful.

Table 3

Participants' personality traits $(N=888)$

\begin{tabular}{|c|c|c|c|c|c|c|c|c|c|c|}
\hline \multirow{2}{*}{ Personality } & \multicolumn{2}{|c|}{ IS $(n=433)$} & \multicolumn{2}{|c|}{$\operatorname{MCS}(n=270)$} & \multicolumn{2}{|c|}{ OCS $(n=99)$} & \multicolumn{2}{|c|}{ HKM $(n=86)$} & \multicolumn{2}{|c|}{ Total $(\mathrm{N}=888)$} \\
\hline & Mean & SD & Mean & SD & Mean & SD & Mean & SD & Mean & SD \\
\hline Extraversion & 26.34 & 5.25 & 27.10 & 5.13 & 25.28 & 5.52 & 24.73 & 4.82 & 26.30 & 5.25 \\
\hline Agreeableness & 33.69 & 5.00 & 34.58 & 4.56 & 32.67 & 4.61 & 31.60 & 4.51 & 33.64 & 4.85 \\
\hline Conscientiousness & 31.66 & 5.41 & 30.36 & 5.03 & 29.49 & 5.04 & 27.03 & 4.66 & 30.57 & 5.36 \\
\hline Neuroticism & 21.20 & 5.31 & 20.39 & 4.84 & 21.96 & 5.70 & 23.22 & 5.22 & 21.24 & 5.26 \\
\hline Openness & 34.77 & 5.66 & 35.06 & 6.19 & 33.42 & 5.79 & 31.98 & 5.52 & 34.44 & 5.89 \\
\hline
\end{tabular}

Note. Highest values are in bold face.

\subsection{Intercultural Competencies}

As mentioned earlier, the IES is composed of six factors, namely: behavioral flexibility, interaction relaxation, interactant respect, message skills, identity maintenance, and interaction management. Students are 
The role of personality and intercultural effectiveness towards study abroad academic and social activities

ask to rate their perceived agreement with the various situations. Responses were on a 5 point Likert-type scale, ranging from 1 = "None", 2 = "Very little", 3 = "Some", 4 = "Quite a bit", and 5 = "Very much". Cronbach Alpha reliability of the IES is computed at .86, which can be considered to be as quite reliable results (L. Cohen et al., 2007). Table 5 shows the summary of results of the IES for the various student groups. However, in order to make the results meaningful and further determine if the difference in mean scores between the various IES factors is significant; the ANOVA was also accomplished.

Table 4

ANOVA results for personality traits $(N=888)$

\begin{tabular}{|c|c|c|c|c|c|}
\hline Personality & $S S$ & $F$ & $p$ & Eta squared & Post-hoc \\
\hline Extraversion & 488.79 & 6.01 & .000 & .020 & $\mathrm{IS}>\mathrm{HKM}^{*}, \mathrm{MCS}>\mathrm{OCS} *, \mathrm{MCS}>\mathrm{HKM}^{*}$ \\
\hline Agreeableness & 689.36 & 10.06 & .000 & .033 & $\mathrm{IS}>\mathrm{HKM}^{*}, \mathrm{MCS}>\mathrm{OCS} *, \mathrm{MCS}>\mathrm{HKM}^{*}$ \\
\hline Conscientiousness & 1725.06 & 21.37 & .000 & .068 & $\begin{array}{l}\text { IS }>\mathrm{MCS}^{*}, \text { IS }>\text { OCS } *, \text { IS }>\mathrm{HKM}^{*} \\
\mathrm{MCS}>\mathrm{HKM}^{*}, \text { OCS }>\mathrm{HKM}^{*}\end{array}$ \\
\hline Neuroticism & 586.04 & 7.20 & .000 & .024 & HKM>IS*, HKM>MCS* \\
\hline Openness & 774.85 & 7.61 & .000 & .025 & $\mathrm{IS}>\mathrm{HKM}^{*}, \mathrm{MCS}>\mathrm{HKM}^{*}$ \\
\hline
\end{tabular}

Note. ${ }^{*} p<.05$

Table 5

Intercultural Effectiveness Scale results $(N=888)$

\begin{tabular}{|c|c|c|c|c|c|c|c|c|c|c|}
\hline \multirow{2}{*}{ Factor/Items (Cronbach Alpha reliability) } & \multicolumn{2}{|c|}{ IS $(n=433)$} & \multicolumn{2}{|c|}{$\operatorname{MCS}(n=270)$} & \multicolumn{2}{|c|}{ OCS $(n=99)$} & \multicolumn{2}{|c|}{ HKM $(n=86)$} & \multicolumn{2}{|c|}{ Total $(\mathrm{N}=888)$} \\
\hline & Mean & SD & Mean & SD & Mean & SD & Mean & SD & Mean & $\mathrm{SD}$ \\
\hline Behavioral flexibility $(\alpha=.702)$ & 3.45 & 0.72 & 3.49 & 0.67 & 3.36 & 0.84 & 3.26 & 0.81 & 3.43 & 0.73 \\
\hline $\begin{array}{l}\text { *BF01. I am afraid to express myself when interacting with } \\
\text { people from different cultures }\end{array}$ & 3.84 & 1.03 & 4.04 & 0.90 & 3.71 & 1.09 & 3.69 & 1.01 & 3.87 & 1.00 \\
\hline $\begin{array}{l}\text { *BF02. I am not always the person I appear to be when } \\
\text { interacting with people from different cultures }\end{array}$ & 3.69 & 1.09 & 3.76 & 1.01 & 3.43 & 1.08 & 3.31 & 1.04 & 3.64 & 1.07 \\
\hline $\begin{array}{l}\text { *BF03. I often act like a very different person when } \\
\text { interacting with people from different cultures }\end{array}$ & 3.91 & 1.06 & 3.89 & 0.96 & 3.55 & 1.15 & 3.41 & 1.08 & 3.81 & 1.06 \\
\hline $\begin{array}{l}\text { *BF04. I find the best way to act is to be myself when } \\
\text { interacting with people from different cultures }\end{array}$ & 2.36 & 1.21 & 2.27 & 1.16 & 2.77 & 1.20 & 2.62 & 1.14 & 2.40 & 1.20 \\
\hline Interaction relax $(\alpha=.876)$ & 3.48 & 0.84 & 3.28 & 0.75 & 3.24 & 0.77 & 3.08 & 0.66 & 3.36 & 0.80 \\
\hline $\begin{array}{l}\text { IR01. I find it is easy to talk with people from different } \\
\text { cultures }\end{array}$ & 3.53 & 1.00 & 3.21 & 0.94 & 3.21 & 0.94 & 3.13 & 0.82 & 3.36 & 0.97 \\
\hline $\begin{array}{l}\text { IR02. I find it is easy to get along with people from different } \\
\text { cultures }\end{array}$ & 3.55 & 0.98 & 3.28 & 0.93 & 3.21 & 0.98 & 3.13 & 0.88 & 3.39 & 0.97 \\
\hline $\begin{array}{l}\text { IR03. I always know how to start a conversation when } \\
\text { interacting with people from different cultures }\end{array}$ & 3.33 & 1.07 & 2.99 & 0.98 & 2.98 & 1.05 & 2.76 & 0.95 & 3.14 & 1.05 \\
\hline $\begin{array}{l}\text { IR04. I feel relaxed when interacting with people from } \\
\text { different cultures }\end{array}$ & 3.42 & 1.01 & 3.18 & 0.92 & 3.10 & 0.97 & 2.98 & 0.88 & 3.27 & 0.98 \\
\hline $\begin{array}{l}\text { IR05. I find it is easy to identify with my culturally different } \\
\text { friends during our interaction }\end{array}$ & 3.58 & 0.93 & 3.76 & 0.90 & 3.68 & 0.86 & 3.43 & 0.94 & 3.63 & 0.92 \\
\hline Interactant respect $(\alpha=.845)$ & 4.10 & 0.80 & 4.05 & 0.72 & 3.88 & 0.75 & 3.67 & 0.76 & 4.02 & 0.77 \\
\hline $\begin{array}{l}\text { IS01. I use appropriate eye contact when interacting with } \\
\text { people from different cultures }\end{array}$ & 3.83 & 0.98 & 3.62 & 0.92 & 3.53 & 0.99 & 3.52 & 0.86 & 3.70 & 0.96 \\
\hline $\begin{array}{l}\text { IS02. I always show respect for my culturally different } \\
\text { friends during our interaction }\end{array}$ & 4.24 & 0.87 & 4.27 & 0.81 & 4.07 & 0.80 & 3.73 & 0.80 & 4.18 & 0.85 \\
\hline $\begin{array}{l}\text { IS03. I always show respect for the opinions of my } \\
\text { culturally different friends during our interaction }\end{array}$ & 4.23 & 0.86 & 4.26 & 0.81 & 4.05 & 0.79 & 3.74 & 0.80 & 4.17 & 0.84 \\
\hline Message skills $(\alpha=.842)$ & 3.43 & 0.96 & 3.25 & 0.81 & 3.28 & 0.85 & 3.09 & 0.83 & 3.33 & 0.90 \\
\hline $\begin{array}{l}\text { *MS01. I have problems with grammar when interacting } \\
\text { with people from different cultures }\end{array}$ & 3.28 & 1.15 & 3.07 & 1.01 & 3.15 & 1.04 & 2.94 & 0.87 & 3.17 & 1.08 \\
\hline $\begin{array}{l}\text { *MS02. I have problems distinguishing between informative } \\
\text { and persuasive messages when interacting with people from } \\
\text { different cultures }\end{array}$ & 3.47 & 1.06 & 3.37 & 0.93 & 3.33 & 1.00 & 3.22 & 0.98 & 3.40 & 1.01 \\
\hline $\begin{array}{l}\text { *MS03. I often miss parts of what is going on when } \\
\text { interacting with people from different cultures }\end{array}$ & 3.55 & 1.03 & 3.33 & 0.90 & 3.36 & 1.01 & 3.10 & 0.98 & 3.42 & 1.00 \\
\hline Identity maintenance $(\alpha=.663)$ & 3.47 & 0.66 & 3.44 & 0.66 & 3.29 & 0.66 & 3.19 & 0.62 & 3.41 & 0.66 \\
\hline $\begin{array}{l}\text { *ID01. I find it is difficult to feel my culturally different } \\
\text { friends are similar to me }\end{array}$ & 3.66 & 0.93 & 3.74 & 0.84 & 3.57 & 0.92 & 3.45 & 0.93 & 3.65 & 0.90 \\
\hline $\begin{array}{l}\text { *ID02. I always feel a sense of distance with my culturally } \\
\text { different friends during our interaction }\end{array}$ & 3.63 & 1.00 & 3.41 & 0.98 & 3.36 & 1.07 & 3.23 & 1.05 & 3.50 & 1.02 \\
\hline $\begin{array}{l}\text { ID03. I find I have a lot in common with my culturally } \\
\text { different friends during our interaction }\end{array}$ & 3.11 & 0.98 & 3.17 & 0.84 & 2.94 & 0.95 & 2.87 & 0.87 & 3.09 & 0.93 \\
\hline
\end{tabular}


Wang, W.-L., \& Ching, G. S.

Table 5 continued ...

\begin{tabular}{|c|c|c|c|c|c|c|c|c|c|c|}
\hline \multirow{2}{*}{ Factor/Items (Cronbach Alpha reliability) } & \multicolumn{2}{|c|}{ IS $(n=433)$} & \multicolumn{2}{|c|}{$\operatorname{MCS}(n=270)$} & \multicolumn{2}{|c|}{ OCS $(n=99)$} & \multicolumn{2}{|c|}{ HKM $(n=86)$} & \multicolumn{2}{|c|}{ Total $(\mathrm{N}=888)$} \\
\hline & Mean & SD & Mean & SD & Mean & SD & Mean & SD & Mean & $\mathrm{SD}$ \\
\hline Interaction management $(\alpha=.901)$ & 3.62 & 0.87 & 3.48 & 0.78 & 3.42 & 0.86 & 3.08 & 0.83 & 3.50 & 0.85 \\
\hline $\begin{array}{l}\text { IM01. I am able to express my ideas clearly when } \\
\text { interacting with people from different cultures }\end{array}$ & 3.58 & 0.93 & 3.48 & 0.83 & 3.37 & 0.92 & 3.08 & 0.84 & 3.48 & 0.90 \\
\hline $\begin{array}{l}\text { IM02. I am able to answer questions effectively when } \\
\text { interacting with people from different cultures }\end{array}$ & 3.66 & 0.90 & 3.48 & 0.81 & 3.46 & 0.88 & 3.07 & 0.89 & 3.53 & 0.88 \\
\hline
\end{tabular}

Table 6 shows the ANOVA results with all of the six IES factors having significant differences among the different student groups. In addition, the effect sizes are also provided in terms of Eta squared values. Eta squared values are from .009 to .035 suggesting small (.01 to .05) effect sizes (J. Cohen, 1988). Post-hoc analyses are also provided in Table 6, noting the significant differences between group comparisons. ANOVA results also suggest that the different IES factor differences among the student groups are meaningful. Furthermore, HKM students seem to have the lowest mean scores across all the IES factors (which is also similar with the previous-mentioned personality traits).

Table 6

ANOVA results for IES $(N=888)$

\begin{tabular}{|c|c|c|c|c|c|}
\hline Personality & $S S$ & $F$ & $p$ & Eta squared & Post-hoc \\
\hline Behavior flexibility & 4.15 & 2.61 & .050 & .009 & MCS $>H_{K M}^{*}$ \\
\hline Interaction relax & 16.28 & 8.72 & .000 & .029 & IS $>\mathrm{MCS}^{*}, \mathrm{IS}>\mathrm{OCS} *, \mathrm{IS}>\mathrm{HKM}^{*}$ \\
\hline Interactant respect & 15.61 & 8.90 & .000 & .029 & IS $>\mathrm{HKM}^{*}, \mathrm{MCS}>\mathrm{HKM}^{*}$ \\
\hline Message skills & 11.25 & 4.73 & .003 & .016 & IS $>\mathrm{HKM}^{*}$ \\
\hline Identity maintenances & 7.46 & 5.81 & .001 & .019 & IS $>\mathrm{HKM}^{*}, \mathrm{MCS}>\mathrm{HKM}^{*}$ \\
\hline Interaction management & 22.37 & 10.64 & .000 & .035 & IS $>\mathrm{HKM}^{*}, \mathrm{MCS}>\mathrm{HKM}^{*}, \mathrm{OCS}>\mathrm{HKM}^{*}$ \\
\hline
\end{tabular}
Note. ${ }^{*} p<.05$

\subsection{Gender differences among the students' personality and IES factors $(N=888)$}

During the previous sections, the analyses are focused on the different student groups. For the current section, the analyses shall focus on the gender differences among the students' personality and IES factors. To accomplish this, several independent sample T-tests are used. Table 7 shows the result of the various t-test analyses. Findings show that gender differences exist on the personality traits conscientiousness, neuroticism, and openness with Eta squared values of .005 to .012 signifying small effect sizes (J. Cohen, 1988). In addition, IES factors interaction relax and interaction management, also both shows to have significant gender differences with Eta squared value of .014 and .007, also denoting small effect sizes. Such results denote that male students are better in handling themselves during interaction with foreign cultures on both interaction relax and interaction management factors.

\section{Table 7}

T-test results on students' gender $(N=888)$

\begin{tabular}{llllccccc}
\hline Factors / Personality traits & Gender & Mean & SD & $F$ & $t$ & $p$ & $M D$ & Eta squared \\
\hline Extraversion & Female & 26.17 & 5.33 & 0.33 & -0.80 & .426 & -0.28 & .001 \\
Agreeableness & Male & 26.45 & 5.16 & & & & & \\
& Female & 33.55 & 4.90 & 0.39 & -0.57 & .570 & -0.19 & .000 \\
Conscientiousness & Male & 33.74 & 4.80 & & & & & .012 \\
Neuroticism & Female & 30.00 & 5.40 & 0.08 & $\mathbf{- 3 . 3 4}$ & .001 & -1.20 & .010 \\
\multirow{2}{*}{ Openness } & Male & 31.20 & 5.26 & & & & & \\
& Female & 21.74 & 5.32 & 0.02 & $\mathbf{2 . 9 6}$ & .003 & 1.04 & .005 \\
& Male & 20.69 & 5.15 & & & & & \\
\end{tabular}


The role of personality and intercultural effectiveness towards study abroad academic and social activities

Table 7 continued ...

\begin{tabular}{|c|c|c|c|c|c|c|c|c|}
\hline Factors / Personality traits & Gender & Mean & SD & $F$ & $t$ & $p$ & $M D$ & Eta squared \\
\hline \multirow[t]{2}{*}{ Behavior flexibility } & Female & 3.40 & 0.69 & 3.21 & -1.57 & .116 & -0.08 & .003 \\
\hline & Male & 3.47 & 0.77 & & & & & \\
\hline \multirow{2}{*}{ Interaction relax } & Female & 3.27 & 0.79 & 0.08 & -3.51 & .000 & -0.19 & .014 \\
\hline & Male & 3.45 & 0.80 & & & & & \\
\hline \multirow[t]{2}{*}{ Interactant respect } & Female & 4.03 & 0.76 & 0.14 & 0.49 & .623 & 0.03 & 000 \\
\hline & Male & 4.01 & 0.79 & & & & & \\
\hline \multirow{2}{*}{ Message skills } & Female & 3.31 & 0.85 & 6.36 & -0.72 & .473 & -0.04 & .001 \\
\hline & Male & 3.35 & 0.94 & & & & & \\
\hline \multirow[t]{2}{*}{ Identity maintenances } & Female & 3.38 & 0.65 & 0.62 & -1.58 & .114 & -0.07 & .003 \\
\hline & Male & 3.45 & 0.67 & & & & & \\
\hline \multirow[t]{2}{*}{ Interaction management } & Female & 3.43 & 0.84 & 0.25 & -2.44 & .015 & -0.14 & .007 \\
\hline & Male & 3.57 & 0.86 & & & & & \\
\hline
\end{tabular}

Note. Male $n=427$, Female $n=461$. Significant t-values are in bold.

\subsection{Correlational analysis}

To better understand the relationships between the factors, Pearson correlation analyses are accomplished. Table 8 shows that all of the IES factors are quite correlated with each other. In addition, all of the personality traits except neuroticism are positively correlated with the IES factors, while neuroticism is negatively correlated with the IES factors. Similarly, the personality traits extraversion, agreeableness, conscientiousness, and openness are positively correlated with each other, while negatively correlated with neuroticism. This would mean that quite emotionally unstable students are low in extraversion, agreeableness, conscientiousness, and openness to new experiences. Hence, such individual would also score significantly low on the various IES factors. These results indicate that a high in neuroticism student would tend to have difficulties in interacting with a new or foreign culture.

\section{Table 8}

Correlational analysis of the various factors $(N=888)$

\begin{tabular}{|c|c|c|c|c|c|c|c|c|c|c|c|c|}
\hline Factors/Traits & & $\mathrm{BF}$ & IR & IS & MS & ID & IM & Ex & $\mathrm{Ag}$ & Co & $\mathrm{Ne}$ & Op \\
\hline \multirow[t]{2}{*}{$\overline{\mathrm{BF}}$} & $r$ & 1 & & & & & & & & & & \\
\hline & $p$ & & & & & & & & & & & \\
\hline \multirow[t]{2}{*}{ IR } & $r$ & $.254^{* * *}$ & 1 & & & & & & & & & \\
\hline & $p$ & .000 & & & & & & & & & & \\
\hline \multirow[t]{2}{*}{ IS } & $r$ & $.098 * *$ & $.541 * *$ & 1 & & & & & & & & \\
\hline & $p$ & .003 & .000 & & & & & & & & & \\
\hline \multirow[t]{2}{*}{ MS } & $r$ & $.366^{* * *}$ & $.167 * *$ & $.087 * *$ & 1 & & & & & & & \\
\hline & $p$ & .000 & .000 & .009 & & & & & & & & \\
\hline \multirow[t]{2}{*}{ ID } & $r$ & $.345^{* *}$ & $.379 * *$ & $.270 * *$ & $.420 * *$ & 1 & & & & & & \\
\hline & $p$ & .000 & .000 & .000 & .000 & & & & & & & \\
\hline \multirow[t]{2}{*}{$\mathrm{IM}$} & $r$ & $.234 * *$ & $.584 * *$ & $.476^{* *}$ & $.261 * *$ & $.392 * *$ & 1 & & & & & \\
\hline & $p$ & .000 & .000 & .000 & .000 & .000 & & & & & & \\
\hline \multirow[t]{2}{*}{ Ex } & $r$ & $.366^{* * *}$ & $.426 * *$ & $.279 * *$ & $.208 * *$ & $.297 * *$ & $.377 * *$ & 1 & & & & \\
\hline & $p$ & .000 & .000 & .000 & .000 & .000 & .000 & & & & & \\
\hline \multirow[t]{2}{*}{$\mathrm{Ag}$} & $r$ & $.231 * *$ & $.277 * *$ & $.398 * *$ & $.217 * *$ & $.313 * *$ & $.235 * *$ & $.330 * *$ & 1 & & & \\
\hline & $p$ & .000 & .000 & .000 & .000 & .000 & .000 & .000 & & & & \\
\hline \multirow[t]{2}{*}{$\mathrm{Co}$} & $r$ & $.284 * *$ & $.327 * *$ & $.285^{* *}$ & $.281 * *$ & $.308 * *$ & $.328 * *$ & $.407 * *$ & $.406 * *$ & 1 & & \\
\hline & $p$ & .000 & .000 & .000 & .000 & .000 & .000 & .000 & .000 & & & \\
\hline \multirow[t]{2}{*}{$\mathrm{Ne}$} & $r$ & $-.371 * *$ & $-.314 * *$ & $-.255 * *$ & $-.286 * *$ & $-.324 * *$ & $-.259 * *$ & $-.477 * *$ & $-.515 * *$ & $-.506^{* *}$ & 1 & \\
\hline & $p$ & .000 & .000 & .000 & .000 & .000 & .000 & .000 & .000 & .000 & & \\
\hline \multirow[t]{2}{*}{ Op } & $r$ & $.102 * *$ & $.344 * *$ & $.339 * *$ & $.091 * *$ & $.222 * *$ & $.321 * *$ & $.352 * *$ & $.233 * *$ & $.333^{* * *}$ & $-.151 * *$ & 1 \\
\hline & $p$ & .002 & .000 & .000 & .007 & .000 & .000 & .000 & .000 & .000 & .000 & \\
\hline
\end{tabular}

\subsection{Study abroad activities}

To better understand how the study abroad students are doing, additional questions regarding their academic 
Wang, W.-L., \& Ching, G. S.

and social interaction activities are ask. Questions ask are as follows: the frequency and satisfaction of studying and going out on their own, with local Taiwan students and friends, with other international students, and with other students from their own country. Responses were on a 5 point Likert-type scale, ranging from $1=$ "None", 2 = "Very little", 3 = "Some", 4 = "Quite a bit", and 5 = "Very much". Cronbach Alpha reliability of the study abroad activities are computed to be at .82, which can be considered to be as quite reliable results (L. Cohen et al., 2007).

Table 9 shows the results wherein IS seems to score the highest among the frequency of studying on their own and with other international students, going out on their own and with other international students. Furthermore, they are also quite satisfied with their studying on their own, with other international students, and with students from their home country, and going out with other international students and with friends from their home country. MCS score highest on the frequency of studying with students from their home country, while quite satisfied in studying and going out with their local Taiwanese classmates, and going out on their own. For the HKM, they score highest on the frequency of studying and going out with their Taiwanese classmates, while the OCS score highest on the frequency of going out with friends from their home country. Generally speaking, students are quite satisfied with their studies and going out activities.

To check whether these scores are statistically meaningful, ANOVA analyses were accomplished. Table 10 shows the ANOVA results, wherein significant differences were found on the frequencies of studying on their own, with their Taiwanese classmates, and with other international students, and the frequencies of going out on their own, with their Taiwanese classmates, and with other international students. In addition, significant differences were also found on the satisfaction of studying on their own and with other international students, and going out with other international students. Post-hoc comparisons are also provided (mean scores with significant Tukey values).

Table 9

Frequency and satisfaction of studying and going out activities $(N=888)$

\begin{tabular}{|c|c|c|c|c|c|c|c|c|c|c|}
\hline \multirow{2}{*}{ Factors } & \multicolumn{2}{|c|}{ IS $(n=433)$} & \multicolumn{2}{|c|}{$\operatorname{MCS}(n=270)$} & \multicolumn{2}{|c|}{ OCS $(n=99)$} & \multicolumn{2}{|c|}{ HKM $(n=86)$} & \multicolumn{2}{|c|}{ Total $(\mathrm{N}=888)$} \\
\hline & Mean & SD & Mean & SD & Mean & SD & Mean & SD & Mean & SD \\
\hline \multicolumn{11}{|l|}{ Frequency } \\
\hline Studying on my own & 4.07 & 0.78 & 3.86 & 0.88 & 3.85 & 0.96 & 3.66 & 0.95 & 3.94 & 0.86 \\
\hline Studying with my Taiwanese classmates & 2.25 & 1.08 & 2.19 & 0.97 & 2.18 & 1.09 & 2.72 & 1.11 & 2.27 & 1.06 \\
\hline Studying with other international students & 2.48 & 1.16 & 1.50 & 0.84 & 2.07 & 1.21 & 2.12 & 1.15 & 2.10 & 1.16 \\
\hline Studying with students from my home country & 2.53 & 1.31 & 2.64 & 1.20 & 2.62 & 1.26 & 2.70 & 1.39 & 2.59 & 1.28 \\
\hline Going out on my own & 3.13 & 1.13 & 2.89 & 0.96 & 3.15 & 1.06 & 3.05 & 1.01 & 3.05 & 1.07 \\
\hline Going out with my Taiwanese friends & 2.75 & 1.06 & 2.47 & 0.90 & 2.88 & 1.02 & 3.07 & 0.94 & 2.71 & 1.01 \\
\hline Going out with other international students & 2.85 & 1.18 & 1.66 & 0.88 & 2.55 & 1.27 & 2.14 & 1.12 & 2.39 & 1.22 \\
\hline Going out with friends from my home country & 3.33 & 1.20 & 3.39 & 1.01 & 3.43 & 1.11 & 3.38 & 1.10 & 3.36 & 1.12 \\
\hline \multicolumn{11}{|l|}{ Satisfaction } \\
\hline Studying on my own & 4.02 & 0.89 & 3.95 & 0.93 & 3.85 & 0.89 & 3.66 & 0.97 & 3.94 & 0.92 \\
\hline Studying with my Taiwanese classmates & 3.29 & 1.21 & 3.42 & 1.19 & 3.17 & 1.19 & 3.34 & 1.15 & 3.32 & 1.20 \\
\hline Studying with other international students & 3.46 & 1.13 & 2.83 & 1.41 & 2.93 & 1.34 & 2.79 & 1.36 & 3.14 & 1.31 \\
\hline Studying with students from my home country & 3.54 & 1.22 & 3.56 & 1.11 & 3.31 & 1.28 & 3.28 & 1.23 & 3.49 & 1.20 \\
\hline Going out on my own & 3.88 & 1.02 & 3.92 & 1.00 & 3.89 & 0.98 & 3.83 & 0.91 & 3.89 & 1.00 \\
\hline Going out with my Taiwanese friends & 3.79 & 1.08 & 3.80 & 1.07 & 3.67 & 1.09 & 3.78 & 0.91 & 3.78 & 1.06 \\
\hline Going out with other international students & 3.81 & 1.09 & 3.06 & 1.42 & 3.40 & 1.23 & 3.14 & 1.29 & 3.47 & 1.28 \\
\hline Going out with friends from my home country & 4.11 & 0.95 & 4.00 & 0.86 & 3.91 & 1.02 & 3.93 & 0.99 & 4.03 & 0.94 \\
\hline
\end{tabular}

To further understand the relationship of the frequency of students' activities and the various IES and personality traits; correlational analyses are accomplished. Table 11 shows that the students' personality trait of extraversion has a tendency to be positively correlated with studying and going out with other individuals. While, the personality trait of agreeableness tends to be negatively correlated with going out on their own. In addition, students who are conscientiousness tends to be positively correlated with studying on their own and studying and going out with other international students. Results also shows that the personality trait of openness tends to be positively correlated with studying and going out on their own, and going out with other international students, 
The role of personality and intercultural effectiveness towards study abroad academic and social activities

while having negative correlation with studying with classmates from their home country and going out with friends from their home country. Lastly, the personality trait of neuroticism seems to show no significant correlation among the various activities.

\section{Table 10}

ANOVA results for students' activities $(N=888)$

\begin{tabular}{|c|c|c|c|c|c|}
\hline Items & SS & $F$ & $p$ & Eta squared & Comparison \\
\hline \multicolumn{6}{|l|}{ Frequency } \\
\hline Studying on my own & 16.43 & 7.61 & .000 & .025 & $\mathrm{IS}>\mathrm{MCS}^{*}, \mathrm{IS}>\mathrm{HKM} *$ \\
\hline Studying with my Taiwanese classmates & 20.14 & 6.04 & .000 & .020 & $\begin{array}{l}\mathrm{HKM}>\mathrm{IS} *, \mathrm{HKM}>\mathrm{MCS} * \\
\mathrm{HKM}>\mathrm{OCS} *\end{array}$ \\
\hline Studying with other international students & 158.75 & 45.46 & .000 & .134 & $\begin{array}{l}\mathrm{IS}>\mathrm{MCS}^{*}, \mathrm{IS}>\mathrm{OCS} *, \mathrm{IS}>\mathrm{HKM}^{*}, \\
\mathrm{HKM}>\mathrm{MCS}^{*}\end{array}$ \\
\hline Studying with students from my home country & 3.40 & 0.69 & .559 & .002 & \\
\hline Going out on my own & 10.92 & 3.21 & .022 & 011 & $\mathrm{IS}>\mathrm{MCS}^{*}$ \\
\hline Going out with my Taiwanese friends & 29.77 & 9.97 & .000 & .033 & $\begin{array}{l}\mathrm{IS}>\mathrm{MCS} *, \mathrm{OCS}>\mathrm{MCS} *, \mathrm{HKM}>\mathrm{IS} * \text {, } \\
\mathrm{HKM}>\mathrm{MCS}^{*}\end{array}$ \\
\hline Going out with other international students & 244.45 & 67.32 & .000 & .186 & $\begin{array}{l}\mathrm{IS}>\mathrm{MCS} *, \mathrm{IS}>\mathrm{HKM}^{*}, \mathrm{OCS}>\mathrm{MCS} * \\
\mathrm{HKM}>\mathrm{MCS} *\end{array}$ \\
\hline Going out with friends from my home country & 1.21 & 0.32 & .812 & .001 & \\
\hline \multicolumn{6}{|l|}{ Satisfaction } \\
\hline Studying on my own & 10.12 & 4.07 & .007 & .014 & IS>HKM* \\
\hline Studying with my Taiwanese classmates & 5.38 & 1.26 & .288 & .004 & \\
\hline Studying with other international students & 86.37 & 17.88 & .000 & .057 & IS>MCS*, IS>OCS*, IS>HKM* \\
\hline Studying with students from my home country & 8.99 & 2.10 & .099 & .007 & \\
\hline Going out on my own & 0.65 & 0.22 & .885 & .001 & \\
\hline Going out with my Taiwanese friends & 1.40 & 0.41 & .743 & .001 & \\
\hline Going out with other international students & 106.44 & 23.29 & .000 & .073 & IS $>\mathrm{MCS}^{*}, \mathrm{IS}>\mathrm{OCS} *, \mathrm{IS}>\mathrm{HKM}^{*}$ \\
\hline Going out with friends from my home country & 5.11 & 1.95 & .120 & 007 & \\
\hline
\end{tabular}

As for the correlation of the frequency of activities with the IES factors, some interesting findings are the negative correlation of message skills (MS) and identity maintenance (ID) with studying and going out with students and friends from their home country, which would be quite odd since students should be able to speak their own local language and understand (interact) better within their own culture. Results also show that message skills (MS) is negatively correlated with going out on their own, which would mean that the better they are in their conveying of message the less the students tends to go out in their own; somewhat contradicting with the notion of not being afraid of interacting with foreigners since they are capable of understanding contextual messages.

\section{Table 11}

Correlation between frequency of students' activities and various IES factors and personality traits $(N=888)$

\begin{tabular}{|c|c|c|c|c|c|c|c|c|c|c|c|}
\hline Items & $\mathrm{BF}$ & IR & IS & MS & ID & IM & Ex & $\mathrm{Ag}$ & $\mathrm{Co}$ & $\mathrm{Ne}$ & Op \\
\hline \multirow[t]{2}{*}{ Studying on my own } & $r-.007$ & $.106^{* *}$ & $.144 * *$ & -.017 & .013 & $.121 * *$ & -.009 & .061 & $.141 * *$ & .028 & $.126 * *$ \\
\hline & p. .831 & .002 & .000 & .612 & .702 & .000 & .799 & .071 & .000 & .398 & .000 \\
\hline \multirow[t]{2}{*}{ Studying with my Taiwanese classmates } & $r .046$ & $.082 *$ & -.048 & -.050 & .044 & .048 & $.113 * *$ & .010 & .041 & -.050 & .005 \\
\hline & $p .172$ & .015 & .152 & .138 & .187 & .152 & .001 & .777 & .218 & .134 & .874 \\
\hline \multirow[t]{2}{*}{ Studying with other international students } & $r .078 *$ & $.183^{* *}$ & -.018 & .036 & .037 & $.078 *$ & $.124 * *$ & -.038 & $.137 * *$ & -.014 & .046 \\
\hline & p.020 & .000 & .599 & .288 & .275 & 0.02 & .000 & .253 & .000 & .673 & .173 \\
\hline \multirow{2}{*}{ Studying with students from my home country } & $r-.001$ & .002 & -.042 & $-.077 *$ & $-.076 *$ & -.041 & $.108 * *$ & -.031 & .007 & .009 & $-.082 *$ \\
\hline & p.983 & .959 & .214 & .021 & .024 & .219 & .001 & .355 & .825 & .778 & .015 \\
\hline \multirow[t]{2}{*}{ Going out on my own } & $r-.030$ & $.099 * *$ & .064 & $-.083^{*}$ & -.016 & $.085 *$ & .044 & $-.097 * *$ & .043 & .060 & $.111 * *$ \\
\hline & p. 376 & .003 & .057 & .013 & .643 & .011 & .191 & .004 & .202 & .073 & .001 \\
\hline \multirow[t]{2}{*}{ Going out with my Taiwanese friends } & $r .045$ & $.211 * *$ & .056 & .036 & $.124 * *$ & $.154 * *$ & $.131 * *$ & .041 & .039 & -.062 & .054 \\
\hline & p. 182 & .000 & .094 & .283 & .000 & .000 & .000 & .220 & .249 & .063 & .107 \\
\hline \multirow[t]{2}{*}{ Going out with other international students } & $r .085^{*}$ & $.252 * *$ & .025 & $.099 * *$ & $.113 * *$ & $.182 * *$ & $.143 * *$ & -.038 & $.113 * *$ & -.008 & $.117 * *$ \\
\hline & $p .012$ & .000 & .450 & .003 & .001 & .000 & .000 & .260 & .001 & .806 & .000 \\
\hline \multirow[t]{2}{*}{ Going out with friends from my home country } & $r-.028$ & -.041 & .008 & $-.078 *$ & $-.097 * *$ & -.055 & .042 & .033 & -.026 & .022 & $-.105 * *$ \\
\hline & p. 398 & .227 & .808 & .019 & .004 & .102 & .213 & .329 & .444 & .510 & .002 \\
\hline
\end{tabular}

Note. $* * p<.001, * p<.05$, Values of interest are shaded

$\mathrm{BF}=$ behavioral flexibility, $\mathrm{IR}=$ interaction relaxation, $\mathrm{IS}=$ interactant respect, $\mathrm{MS}=$ message skills, ID=identity maintenance, $\mathrm{IM}=$ interaction management, $\mathrm{Ex}=$ extraversion, $\mathrm{Ag}=$ agreeableness, $\mathrm{Co}=$ conscientiousness, Ne-neuroticism, Op=openness 
Wang, W.-L., \& Ching, G. S.

As for the correlations of students' perceived satisfaction with their various activities and IES factors, Table 12 shows that almost all (except for a few) of the IES factors are positively correlated with the students' satisfaction. Similarly, the personality traits of extraversion, agreeableness, conscientiousness, and openness are also positively correlated with the students' satisfaction, while the trait neuroticism is negatively correlated with the students' satisfaction.

\section{Table 12}

Correlation between satisfaction of students' activities and various IES factors and personality traits $(N=888)$

\begin{tabular}{|c|c|c|c|c|c|c|c|c|c|c|c|}
\hline Items & $\mathrm{BF}$ & IR & IS & MS & ID & IM & Ex & $\mathrm{Ag}$ & $\mathrm{Co}$ & $\mathrm{Ne}$ & Op \\
\hline \multirow[t]{2}{*}{ Studying on my own } & $r .089 * *$ & $.184 * *$ & $.201 * *$ & $.098 * *$ & $.137 * *$ & $.170 * *$ & $.175^{* * *}$ & $.148 * *$ & $.306 * *$ & $-.190 * *$ & $.180^{* * *}$ \\
\hline & $p .008$ & .000 & .000 & .003 & .000 & .000 & .000 & .000 & .000 & .000 & .000 \\
\hline \multirow[t]{2}{*}{ Studying with my Taiwanese classmates } & $r .125^{* *}$ & $.170 * *$ & $.121 * *$ & .025 & $.168 * *$ & $.168 * *$ & $.153 * *$ & $.145 * *$ & $.166^{* *}$ & $-.156 * *$ & $.121 * *$ \\
\hline & $p .000$ & .000 & .000 & .449 & .000 & .000 & .000 & .000 & .000 & .000 & .000 \\
\hline \multirow[t]{2}{*}{ Studying with other international students } & $r .146^{* *}$ & $214 * *$ & $.120 * *$ & .066 & $.148 * *$ & $.155^{* *}$ & $.150 * *$ & $.115^{* *}$ & $.201 * *$ & $-.134 * *$ & $.126^{* *}$ \\
\hline & $p .000$ & .000 & .000 & .051 & .000 & .000 & .000 & .001 & .000 & .000 & .000 \\
\hline \multirow[t]{2}{*}{ Studying with students from my home country } & $r .114 * *$ & $.132 * *$ & $.133 * *$ & .023 & $.079 *$ & $.118 * *$ & $.165^{* * *}$ & $.145 * *$ & $.198 * *$ & $-.169 * *$ & $.073^{*}$ \\
\hline & $p .001$ & .000 & .000 & .498 & .019 & .000 & .000 & .000 & .000 & .000 & .030 \\
\hline \multirow[t]{2}{*}{ Going out on my own } & $r .042$ & $.203 * *$ & $.213 * *$ & .022 & $.136^{* *}$ & $.201 * *$ & $.158 * *$ & $.120 * *$ & $.129 * *$ & $-.156 * *$ & $.210^{* *}$ \\
\hline & p. .214 & .000 & .000 & .520 & .000 & .000 & .000 & .000 & .000 & .000 & .000 \\
\hline \multirow[t]{2}{*}{ Going out with my Taiwanese friends } & $r .084 *$ & $.256^{* *}$ & $.238 * *$ & $.077 *$ & $.195 * *$ & $.236 * *$ & $.166^{* * *}$ & $.181 * *$ & $.137 * *$ & $-.171 * *$ & $.175^{* *}$ \\
\hline & p.012 & .000 & .000 & .022 & .000 & .000 & .000 & .000 & .000 & .000 & .000 \\
\hline \multirow[t]{2}{*}{ Going out with other international students } & $r .113^{* * *}$ & $.264 * *$ & $.116 * *$ & $.117 * *$ & $.173 * *$ & $.219 * *$ & $.125 * *$ & $.087 * *$ & $.153 * *$ & $-.102 * *$ & $.168 * *$ \\
\hline & p.001 & .000 & .001 & .000 & .000 & .000 & .000 & .010 & .000 & .002 & .000 \\
\hline \multirow[t]{2}{*}{ Going out with friends from my home country } & $r .085 *$ & $.121 * *$ & $.152 * *$ & $.084 *$ & $.106 * *$ & $.140 * *$ & $.140 * *$ & $.204 * *$ & $.132 * *$ & $-.140 * *$ & .046 \\
\hline & $p .011$ & .000 & .000 & .012 & .002 & .000 & .000 & .000 & .000 & .000 & .168 \\
\hline
\end{tabular}

Note. $\quad * * p<.001, * p<.05$, Values of interest are shaded.

$\mathrm{BF}=$ behavioral flexibility, $\mathrm{IR}=$ interaction relaxation, $\mathrm{IS}=$ interactant respect, $\mathrm{MS}=$ message skills, $\mathrm{ID}=\mathrm{identity}$ maintenance,

$\mathrm{IM}=$ interaction management, $\mathrm{Ex}=$ extraversion, $\mathrm{Ag}=$ agreeableness, $\mathrm{Co}=$ conscientiousness, Ne-neuroticism, $\mathrm{Op}=\mathrm{openness}$

Lastly, for the correlation among the frequency and satisfaction of students' activities, Table 13 shows the various results from the analyses. It would seem that many of the frequency activities are quite related to their satisfaction. No negative correlations are found, suggesting that the more the students undertake such activities, the more satisfaction they get. This would be self-explanatory, since students that did not enjoy the activity would not do the same activity next time.

\section{Table 13}

Correlation between frequency and satisfaction of students' activities ( $N=888)$

\begin{tabular}{|c|c|c|c|c|c|c|c|c|}
\hline Frequency items / Satisfaction items & (1) & (2) & (3) & (4) & (5) & (6) & (7) & (8) \\
\hline \multirow{2}{*}{ Studying on my own (1) } & $r .338 * *$ & -.022 & .055 & -.024 & $.160 * *$ & $.072 *$ & $.092 * *$ & .025 \\
\hline & p.000 & .508 & .102 & .484 & .000 & .031 & .006 & .459 \\
\hline \multirow[t]{2}{*}{ Studying with my Taiwanese classmates (2) } & $r .051$ & $.404 * *$ & $.197 * *$ & $.166^{* *}$ & -.001 & $.169 * *$ & $.073 *$ & $.078 *$ \\
\hline & p.126 & .000 & .000 & .000 & .983 & .000 & .029 & .020 \\
\hline \multirow[t]{2}{*}{ Studying with other international students (3) } & $r .049$ & $.107 * *$ & $.461 * *$ & $.135 * *$ & .004 & .032 & $.314 * *$ & .042 \\
\hline & p.144 & .001 & .000 & .000 & .909 & .334 & .000 & .217 \\
\hline \multirow[t]{2}{*}{ Studying with students from my home country (4) } & $r .016$ & $.106^{* *}$ & $.094 * *$ & $.416^{* *}$ & -.017 & -.014 & -.022 & $.198 * *$ \\
\hline & p.632 & .002 & .005 & .000 & .617 & .677 & .509 & .000 \\
\hline \multirow[t]{2}{*}{ Going out on my own (5) } & $r .082 *$ & .003 & $.077 *$ & -.036 & $.368^{* *}$ & $.072 *$ & $.107 * *$ & $-.075^{*}$ \\
\hline & $p .014$ & .934 & .021 & .280 & .000 & .031 & .001 & .026 \\
\hline \multirow[t]{2}{*}{ Going out with my Taiwanese friends (6) } & $r .040$ & $.204^{* *}$ & $.159 * *$ & .062 & $.109^{* *}$ & $.460 * *$ & $.178^{* *}$ & .058 \\
\hline & p. 233 & .000 & .000 & .065 & .001 & .000 & .000 & .085 \\
\hline \multirow[t]{2}{*}{ Going out with other international students (7) } & $r .071^{*}$ & .048 & $.345 * *$ & $.075^{*}$ & $.083 *$ & .057 & $.526 * *$ & $.084 *$ \\
\hline & $p .035$ & .149 & .000 & .025 & .013 & .088 & .000 & .012 \\
\hline \multirow[t]{2}{*}{ Going out with friends from my home country (8) } & $r .018$ & .015 & .040 & $.264 * *$ & -.031 & -.039 & .029 & $.418^{* * *}$ \\
\hline & $p .584$ & .647 & .237 & .000 & .356 & .245 & .395 & .000 \\
\hline
\end{tabular}

Note. $\quad * * p<.001, * p<.05$, Values of interest are shaded.

\section{Conclusions}

The current study presented the summary of the various findings for the inter-relationship between students' personality, intercultural effectiveness, and their study-abroad activities. At the middle of the fall semester, a total of 888 volunteer students participated in a survey which includes the 44 items BFI-personality inventory and the 20 item Intercultural Effectiveness Scale. Results were tabulated and computed using the software SPSS. Findings show that the various IES factors are positively correlated with BFI factors except neuroticism which is 
The role of personality and intercultural effectiveness towards study abroad academic and social activities

negatively correlated. In addition, results also show that there exists a significant gender difference among the students' interaction relax and management factors, and the personalities of conscientiousness, openness, and neuroticism. Lastly, ANOVA results show that there are significant differences in all the IES and BFI factors with regards to the different student ethnicity groups and study and outing frequencies. Such results indicate that the both study and leisure activities during study abroad are much dependent on the students' personality and their intercultural competencies. Additional findings which would valid additional thoughts are the negative correlations of message skills and identity maintenance with some of the students' activities. As for the current study is a cross-sectional one, findings are limited to the time in collecting the data, a future suggestion would be to conduct a qualitative ethnographic study, which would provide a better understanding on the entire process of acculturation and their related factors.

Acknowledgement: This work is supported in part by the Taiwan Ministry of Science and Technology under grant number NSC 102-2410-H-262-012-SS2. The authors are grateful to the anonymous reviewers for the valuable comments and suggestions that made the manuscript complete.

\section{References}

Allport, G. W., \& Odbert, H. S. (1936). Trait-names: A psycho-lexical study. Psychological Monographs, 47, 1-211. http://dx.doi.org/10.1037/h0093360

Anderson, P. H., Lawton, L., Rexeisen, R. J., \& Hubbard, A. C. (2006). Short-term study abroad and intercultural sensitivity: A pilot study. International Journal of Intercultural Relations, 30(4), 457-469. http://dx.doi.org/10.1016/i.ijintrel.2005.10.004

Atwork. (2009). Cross-sectional vs. longitudinal Studies. Atwork, Winter(55), 2.

Bakalis, S., \& Joiner, T. A. (2004). "Participation in tertiary study abroad programs: The role of personality. International Journal of Educational Management, 18(5), 286-291. http://dx.doi.org/10.1108/09513540410543420

Best, J. W. (1970). Research in education. Englewood Cliffs, NJ: Prentice Hall.

Biggs, J., \& Tang, C. (2007). Teaching for quality learning at university. Maidenhead: Open University Press.

Bochner, S., McLeod, B. M., \& Lin, A. (1977). Friendship patterns of overseas students: A functional model. International Journal of Psychology, 12(4), 277-294. http://dx.doi.org/10.1080/00207597708247396

Byram, M. (1997). Teaching and assessing intercultural communicative competence. Clevedon: Multilingual Matters Limited.

Carlson, J. S., \& Widaman, K. F. (1988). The effects of study abroad during college on attitudes toward other cultures. International Journal of Intercultural Relations, 12(1), 1-17. http://dx.doi.org/10.1016/0147-1767(88)90003-X

Chen, D.-S., \& Chang, M.-K. (2010). Higher education in Taiwan: The crisis of rapid expansion. Retrieved from http://www.isa-sociology.org/universities-in-crisis/?p=417

Chen, G. M., \& Starosta, W. J. (2000). The development and validation of the intercultural sensitivity scale. Paper presented at the 86th Annual Meeting of the National Communication Association. from http://www.eric.ed.gov/PDFS/ED447525.pdf

Chieffo, L., \& Griffiths, L. (2004). Large-scale assessment of student attitudes after a short-term study abroad program. Frontiers: The Interdisciplinary Journal of Study Abroad, 10, 165-177.

Cohen, J. (1988). Statistical power analysis for the behavioral sciences. Hillsdale, NJ: Erlbaum.

Cohen, L., Manion, L., \& Morrison, K. (2007). Research methods in education. New York: Routledge.

Dwyer, M. M. (2004). More is better: The impact of study abroad program duration. Frontiers: The Interdisciplinary Journal of Study Abroad, 10, 151-163.

Fiske, D. W. (1949). Consistency of the factorial structures of personality ratings from different sources. Journal of Abnormal Social Psychology, 44, 329-344. http://dx.doi.org/10.1037/h0057198

Glass, C. R., Gomez, E., \& Urzua, A. (2014). Recreation, intercultural friendship, and international students' adaptation to college by region of origin. International Journal of Intercultural Relations, 42, 104-117. http://dx.doi.org/10.1016/j.ijintrel.2014.05.007

Goldberg, L. R. (1993). The structure of phenotypic personality traits. American Psychologist, 48(1), 26-34. http://dx.doi.org/10.1037/0003-066X.48.1.26

Goldberg, L. R., \& Kilkowski, J. M. (1985). The prediction of semantic consistency in self-descriptions: 
Characteristics of persons and of terms that affect the consistency of responses to synonym and antonym pairs. Journal of Personality and Social Psychology, 48, 82-98. http://dx.doi.org/10.1037/0022-3514.48.1.82

Gurven, M., von Rueden, C., Massenkoff, M., Kaplan, H., \& Lero Vie, M. (2013). How universal is the big five? Testing the five-factor model of personality variation among forager - Farmers in the Bolivian Amazon. Journal of Personality and Social Psychology, 104(2), 354-370. http://dx.doi.org/10.1037/a0030841

Gurven, M., von Rueden, C., Stieglitz, J., Kaplan, H., \& Rodriguez, D. E. (2014). The evolutionary fitness of personality traits in a small-scale subsistence society. Evolution and Human Behavior, 35(1), 17-25. 10.1016/j.evolhumbehav.2013.09.002

Hendrickson, B., Rosen, D., \& Aune, R. K. (2011). An analysis of friendship networks, social connectedness, homesickness, and satisfaction levels of international students. International Journal of Intercultural Relations, 35, 281-295. http://dx.doi.org/10.1016/j.ijintrel.2010.08.001

Hogan, R., \& Hogan, J. (1992). Hogan personality inventory manual. Tulsa, OK: Hogan Assessment Systems.

Hogan, R., Johnson, J., \& Briggs, S. (Eds.). (1997). Handbook of personality psychology. California: Academic Press.

Huang, H.-C., Chen, S.-D., \& Ching, G. S. (2014). Making new friends: Social concepts of study abroad. International Journal of Research Studies in Psychology, 3(5), 63-72. http://dx.doi.org/10.5861/ijrsp.2014.759

Inside Higher Ed. (2013). Study abroad positively impacts personality, study says. Retrieved from https://www.insidehighered.com/quicktakes/2013/07/11/study-abroad-positively-impacts-personality-st udy-says

John, O. P., Donahue, E. M., \& Kentle, R. L. (1991). The big five inventory: Versions $4 a$ and 54. Berkeley, CA: University of California, Berkeley, Institute of Personality and Social Research.

John, O. P., \& Srivastava, S. (1999). The big five trait taxonomy: History, measurement, and theoretical perspectives. In L. A. Pervin \& O. P. John (Eds.), Handbook of personality: Theory and research (pp. 102-138). New York: Gilford.

Leong, C.-H. (2007). Predictive validity of the Multicultural Personality Questionnaire: A longitudinal study on the socio-psychological adaptation of Asian undergraduates who took part in a study-abroad program. International Journal of Intercultural Relations, 31(5), 545-559. http://dx.doi.org/10.1016/j.ijintrel.2007.01.004

Lillyman, S., \& Bennett, C. (2014). Providing a positive learning experience for international students studying at UK universities: A literature review. Journal of Research in International Education, 13(1), 63-75. http://dx.doi.org/10.1177/1475240914529859

Marx, H., \& Moss, D. M. (2011). Please mind the culture gap: Intercultural development during a teacher education study abroad program. Journal of Teacher Education, 62(1), 35-47. http://dx.doi.org/10.1177/0022487110381998

Maslen, G. (2014). Mass movement of the world's students [Electronic Version]. University World News. Retrieved December 9, 2014, from http://www.universityworldnews.com/article.php?story=20140129200018337

McCrae, R. R., \& Costa, P. T., Jr. (1996). Toward a new generation of personality theories: Theoretical contexts for the five factor model. In J. Wiggens (Ed.), The five factor model of personality (pp. 51-87). New York: Guilford Press.

McCrae, R. R., \& Costa, P. T., Jr. (2003). Personality in adulthood, a five-factor theory perspective. New York: Guilford Press. http://dx.doi.org/10.4324/9780203428412

Ministry of Education. (2014). Admission information. Retrieved from http://english.moe.gov.tw/content.asp?mp=1\&CuItem=14419

Norman, W. T. (1963). Toward an adequate taxonomy of personality attributes: Replicated factor structure in peer nomination personality ratings. Journal of Abnormal and Social Psychology, 66, 574-583. http://dx.doi.org/10.1037/h0040291

Norris, E. M., \& Gillespie, J. (2009). How study abroad shapes global careers: Evidence from the United States. Journal of Studies in International Education, 13(3), 382-397. http://dx.doi.org/10.1177/1028315308319740

Orahood, T., Kruze, L., \& Pearson, D. E. (2004). The impact of study abroad on business students' career goals. Frontiers: The Interdisciplinary Journal of Study Abroad, 10, 117-130.

Parsons, R. L. (2010). The effects of an internationalized university experience on domestic students in the United States and Australia. Journal of Studies in International Education, 14(4), 313-334. http://dx.doi.org/10.1177/1028315309331390

Pervin, L. A., \& John, O. P. (Eds.). (1999). Handbook of personality: Theory and research. New York: Gilford. 
The role of personality and intercultural effectiveness towards study abroad academic and social activities

Portalla, T., \& Chen, G.-M. (2010). The development and validation of the intercultural effectiveness scale. Intercultural Communication Studies, 19(3), 21-37.

Potkay, C., \& Allen, B. (1986). Personality: theory, research, and applications. California: Brooks/Cole.

Rammstedt, B., \& John, O. P. (2007). Measuring personality in one minute or less: A 10-item short version of the big five inventory in English and German. Journal of Research in Personality, 41(1), 203-212. http://dx.doi.org/10.1016/j.jrp.2006.02.001

Roy, P., Wandschneider, E., \& Steglitz, I. (2014). Assessing education abroad outcomes: A review the BEVI, IDI, and GPI. East Lansing: Michigan State University Office of Study Abroad.

Sakurai, Y., Pyhältö, K., \& Lindblom-Ylänne, S. (2014). Are Chinese university students more likely to exhibit a Surface approach to learning than other international students in Finland? Journal of Research in International Education, 13(2), 135-148. http://dx.doi.org/10.1177/1475240914540119

Sinicrope, C., Norris, J., \& Watanabe, Y. (2007). Understanding and assessing intercultural competence: A summary of theory, research, and practice. Second Language Studies, 26(1), 1-58.

Tupes, E. C., \& Christal, R. E. (1961). Recurrent personality factors based on trait ratings TX: Aeronautical Systems Division, Personnel Laboratory.

Vande Berg, M., Paige, R. M., \& Lou, K. H. (2012a). Student learning abroad: Paradigms and assumptions. In M. Vande Berg, R. M. Paige \& K. H. Lou (Eds.), Student learning abroad: What our students are learning, what they're not, and what we can do about it (pp. 3-28). Sterling, Virginia: Stylus Publishing.

Vande Berg, M., Paige, R. M., \& Lou, K. H. (Eds.). (2012b). Student learning abroad: What our students are learning, what they're not, and what we can do about it. Sterling, Virginia: Stylus Publishing.

Wang, Q., \& Hannes, K. (2014). Academic and socio-cultural adjustment among Asian international students in the Flemish community of Belgium: A photovoice project. International Journal of Intercultural Relations, 39, 66-81. http://dx.doi.org/10.1016/j.ijintrel.2013.09.013

Williams, C. T., \& Johnson, L. R. (2011). Why can't we be friends? Multicultural attitudes and friendships with international students. International Journal of Intercultural Relations, 35, 41-48. http://dx.doi.org/10.1016/j.ijintrel.2010.11.001

Williams, T. R. (2005). Exploring the impact of study abroad on students' intercultural communication skills: Adaptability and sensitivity. Journal of Studies in International Education, 9(4), 356-371. http://dx.doi.org/10.1177/1028315305277681

Wood, J. (2013). Studying abroad boost students' emotional development. Retrieved from http://psychcentral.com/news/2013/07/05/studying-abroad-boost-students-emotional-development/5684 $\underline{6 . h t m l}$

Zhang, J., \& Goodson, P. (2011a). Acculturation and psychosocial adjustment of Chinese international students: Examining mediation and moderation effects. International Journal of Intercultural Relations, 35, 614-627. http://dx.doi.org/10.1016/j.ijintrel.2010.11.004

Zhang, J., \& Goodson, P. (2011b). Predictors of international students' psychosocial adjustment to life in the United States: A systematic review. International Journal of Intercultural Relations, 35, 139-162. http://dx.doi.org/10.1016/j.ijintrel.2010.11.011

Zimmermann, J., \& Neyer, F. J. (2013). Do we become a different person when hitting the road? Personality development of sojourners. Journal of Personality and Social Psychology, 105(3), 515-530. http://dx.doi.org/10.1037/a0033019 
Wang, W.-L., \& Ching, G. S. 